\title{
Water hyacinth (Eichhornia crassipes) as an indicator to show the absence of Anopheles sundaicus larvae
}

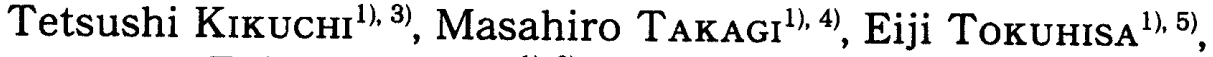 \\ Takeshi Suzuki ${ }^{1,6)}$, William Panjaitan ${ }^{2)}$ \\ and Masayuki YASUNO ${ }^{1,7)}$ \\ 1) North Sumatra Health Promotion Project, Japan International Cooperation Agency, \\ Jalan Prof., H. M. Yamin SH, Medan, Indonesia \\ 2) Provincial Health Service of North Sumatra, Jalan Prof. \\ H. Y. Yamin SH, Medan, Indonesia \\ 3) Department of Medical Zoology, Teikyo University School of Medicine, \\ Itabashi-ku, Tokyo, 173 Japan \\ 4) Department of Medical Entomology, Institute of Tropical Medicine, \\ Nagasaki University, Sakamoto, Nagasaki, 852 Japan \\ 5) Teiso Kasei Co., Ltd., Yamato, Utsunomiya, 321-01 Japan \\ 6) Tamazutsumi, Setagaya-ku, Tokyo, 152 Japan \\ 7) Department of Ecosystem Studies, The University of Shiga Prefecture School of \\ Environmental Science, Hassaka, Hikone, Shiga, 522 Japan
}

(Received: 27 September 1996; Accepted: 17 December 1996)

Key words: Anopheles sundaicus, bio-indicator, Indonesia, brackish water, larval habitat, water hyacinth

\begin{abstract}
Water hyacinth, Eichhornia crassipes, was evaluated as to whether its appearance could be useful as an indicator to show the absence of Anopheles sundaicus larvae in the coastal area of the Asahan Province in North Sumatra, Indonesia. The water hyacinth was distributed along the coast in water bodies in which salinity was less than $0.2 \%$. No An. sundaicus larva was found breeding in waters with hyacinths. In waters without any macrophyte vegetation, the larvae were frequently found in the range of $0.0 \%$ to $4.0 \%$ salinity. The susceptibility test revealed that the plant could not tolerate $0.32 \%$ salinity and began withering, but they were thriving at $0.24 \%$ salinity or less after 2 days exposure. It was concluded that the water hyacinth is a suitable plant for the detecting of $A n$. sundaicus larval habitats and/or brackish water bodies in coastal flats.
\end{abstract}

\section{INTRODUCTION}

Accurate mapping of breeding sites of malaria vectors is essential for effective control. Anopheles sundaicus occurs in brackish water. This species was targeted for malaria vector control in the North Sumatra Health Promotion Project. Ikemoto (1982) reported that the larvae bred in the sunny brackish water at Perupuk village of Asahan Province in the project area. The mapping of the larval breeding sites was intensively done in Perupuk vil- lage. This village was recorded as having the highest prevalence of malaria among six coastal villages in the project area (Kanbara, 1984). Brackish water habitats are very unstable throughout the year. The distribution and area of brackish water frequently changed with rainfall, tidal invasion into the inland area and so on. Therefore, during the survey, we required an indicator which is able to distinguish quickly $A n$. sundaicus larval habitats from water bodies without this species.

The usefulness of the vegetation as a bio- 
indicator to characterize larval habitats is expected to support ecological mapping for mosquito control strongly (Gabinaud, 1987). Some reports have mentioned that water plants related to $A n$. sundaicus larval breeding. Sundararaman et al. (1957) and Collins et al. (1979) reported that $A n$. sundaicus larvae were abundant in the blooms of fibrous floating algae. Chan (1969) also found that profuse numbers of Culex sitiens and An. sundaicus bred together with Entoromorpha sp. in neglected ponds left after fish rearing in Singapore. In the Perupuk area, Ikemoto (1982) reported that Enteromorpha sp. and Chaetomorpha sp. were advantageous for
An. sundaicus as shelter against predators and/or as feeding places. However, the distribution of this plant was very limited and it was seasonal in the study area.

In contrast, the water hyacinth, Eichhornia crassipes, is a floating plant in fresh water areas, and is common throughout Indonesia. We therefore studied whether this plant is useful as a bio-indicator of $A n$. sundaicus larval habitats. We studied the following: (1) distribution of water hyacinths on the Asahan coast; (2) the relationship between distributions of water hyacinths and $A n$. sundaicus larvae; (3) susceptibility of water hyacinths to saline concentrations.

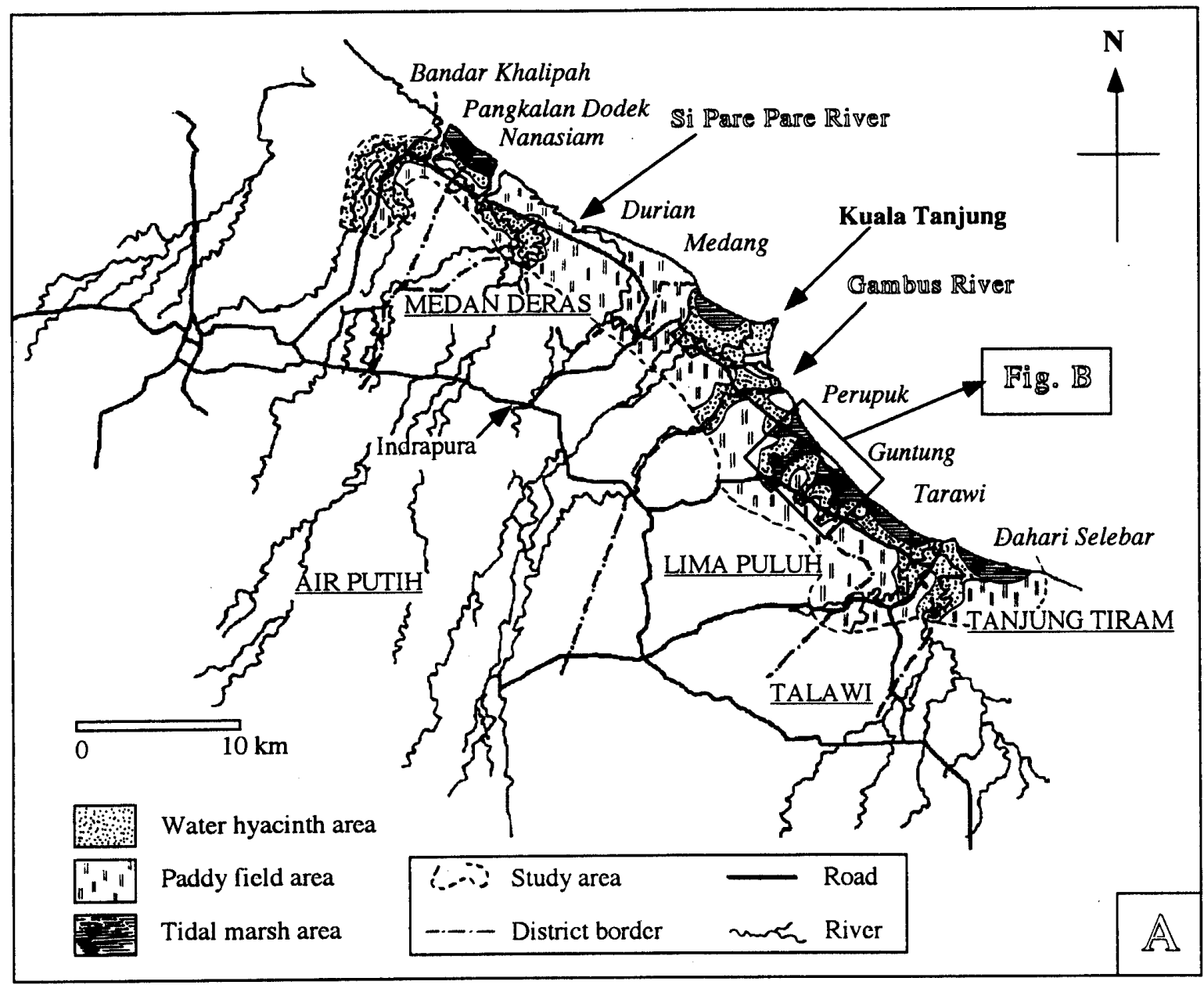

Fig. 1(A).

Fig. 1-A.B. Map of study areas. (A): Environmental conditions along the coast in the Asahan Province. Names of villages are expressed in italics. Names of districts are underlined. Indrapura is the name of the town, and Kuala Tanjung is the name of the cape. (B): Survey sites in Perupuk area. Both sites of water hyacinth 1 and 2 were affected by the spring tide invasion closest in time to the equinox of April in 1986. After this, water hyacinth 1 was covered with duck weed, and water hyacinth 2 was recovered to its former state. Water hyacinth 3 was not invaded by the sea water. 


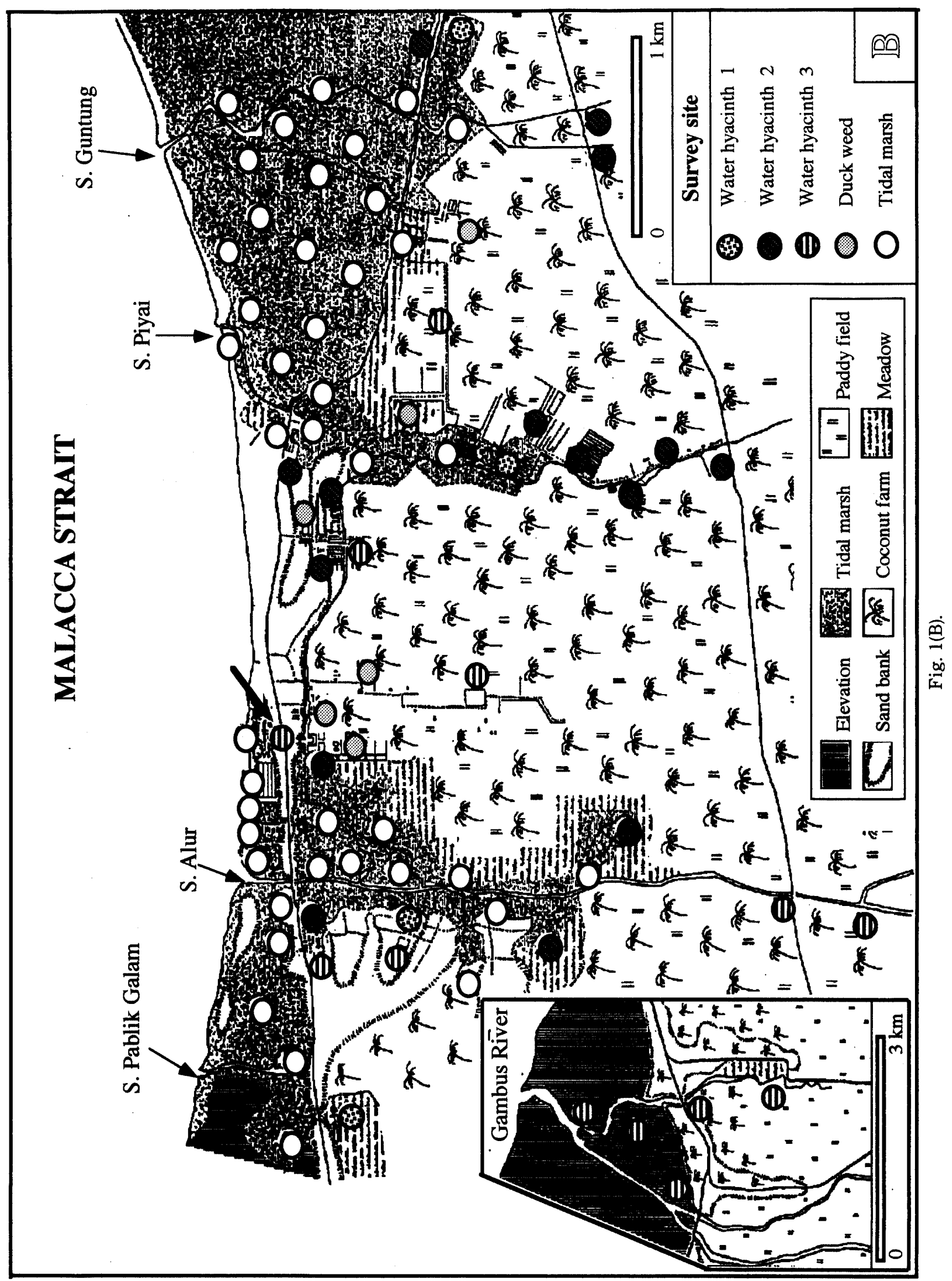




\section{Materials And Methods}

\section{Study area}

The whole study area consisted of 9 villages in Asahan Province facing the Malacca Strait. The distribution of water hyacinths, larval habitat and water salinity were studied in this area (Fig. 1-A). The length of the coastal line surveyed totaled about $56 \mathrm{~km}$ from a part of Bandar Khalipah village to Dahari Selebar village, which were located in the northwest and southeast of Asahan Province, respective$1 \mathrm{y}$.

The distributions of water hyacinth, $A n$. sundaicus larval habitat and water salinity were studied at Perupuk village and parts of Guntung and Pematang Panjang villages (Fig. 1-B). The topography and land use in a part of this area were described by Imai et al. (1988). There is a river, Sungai Gambus, and four tidal creeks where the sea water flows into and out of with the rising and falling of the tide, Sungai Pablik Galam, S. Alur, S. Piyai and S. Guntung, each having a free connection with the sea and a number of substreams. The size and water quality of these tidal creeks were strongly affected by tidal action and rainfall. In the dry season, some streams almost dried up, leaving isolated pools on the stream bed. In contrast, after heavy rainfall, these streams overflowed and large swamps were formed in the meadows.

\section{Survey}

The geographical distributions of water hyacinth and other environmental conditions in the whole study area were surveyed in January 1987. All the water samples were collected from water bodies which were accessible from the road side. The water samples collected with a dipper were quickly spread on the bottom of a white plastic tray, and the existence of $A n$. sundaicus larvae was checked at every sampling point.

At Perupuk village and parts of Gun- tung and Pematang Panjang villages, the relationship of $A n$. sundaicus larval habitat, the distribution of water hyacinth vegetation and the water salinity was examined at 80 sites each of which consisted of 4 collection points. At these points the larval density was examined by 10 to 30 dippings with a dipper $18 \mathrm{~cm}$ in diameter and $10 \mathrm{~cm}$ deep. Salinity was measured at each point by a digital salinometer. The larval density and water salinity obtained from four collection points were averaged at every site and those values were counted each as one sample. This survey was repeated monthly from February to September in 1986. However, if the ground condition prevented entry to the survey site, it was put off till the following month. But even at the longest intervals, it was not put off for more than two months.

Susceptibility test of water hyacinth to salinity

Four water samples of $0.01,0.24,0.32$ and $0.56 \%$ salinity were provided for the examination of the reactions of the water hyacinth's outward appearance to the salinity. Water hyacinths collected from the inland area of Perupuk village were used. Ten individuals were placed into a concrete pond of $1 \mathrm{~m}^{3}$ capacity containing ca. $0.5 \mathrm{t}$ water in each salinity. The examination of their reactions at each salinity was done after 2 days, and 1 and 2 weeks, then the withering of the leaves and roots was carefully observed.

\section{RESUlts}

Distribution of water hyacinths in the Asahan coastal area

The area of the inland side of the road which ran parallel to the seashore, was mostly occupied by paddy fields. The water hyacinths were frequently found along both sides of the rivers and in the irrigation canals spread in the paddy fields. Such places are marked as water hyacinth areas on the water ways in Fig. 1-A. Water salinity was measured at 112 


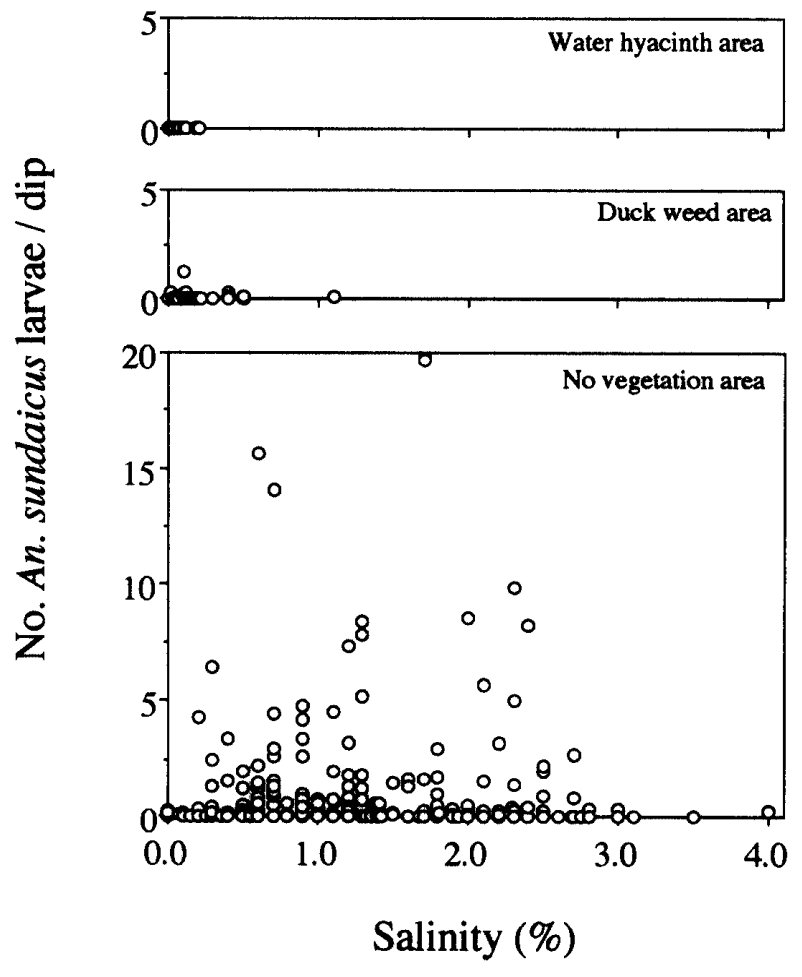

Fig. 2. Correlation of the number of $A n$. sundaicus larvae/dip and water salinity in vegetation and no vegetation areas.

sampling points collected at about $0.5 \mathrm{~km}$ intervals from Bandar Khalipah to Dahari Selebar. But the larval collection by dipping was only done at 67 sampling points due to the configuration of the ground, i.e. the dipper's shaft was too short to reach the water surface or the depth of the water body was too shallow to permit dipping.

Water hyacinth was widely distributed in the direction of the land-sides of Nanasiam and Perupuk to Dahari Selebar, and in the neighborhood of the seashore of Kuala Tanjung (Fig. 1-A). The water hyacinth area occupied $34 \%$ of the whole study area. However, as stated previously, 43\% of this area was at river sides and irrigation canals located in the paddy field area. Twenty-seven samples were collected from this area. No An. sundaicus larva was found. Water salinity was less than $0.2 \%$ in the water where water hyacinths were growing.

The paddy field area occupied $55 \%$ of the whole study area. The paddy fields were supplied with water by several irrigation canals linked to the adjacent rivers.
Durian and Medang in particular were rich in paddy fields supported by eight irrigation canals from the Si Pare Pare river. Twenty-three samples were collected. No $A n$. sundaicus larva was found. Water salinity was less than $0.1 \%$.

The tidal marsh area which was affected by periodic tidal actions occupied only $11 \%$ of the whole study area. It was distributed near the shores of Pangkalang Dodek, on the northwest side of Kuala Tanjung and between Perupuk and Tarawi. There were coves formed by slight curves in the shore. The large tidal areas were formed behind the barrier beach. Seventeen samples were collected. The mean salinity was $1.4 \%$, and $A n$. sundaicus larvae were found in 15 samples.

The distribution of water hyacinth, An. sundaicus larvae and water salinity in the Perupuk area

In the Perupuk area, water hyacinth grew in stagnant water used as ditches for coconut cultivation, fish ponds or what remained as natural flood plains (Fig. 1-B). Near the main stream of the Gambus river, although there was fresh water, water hyacinths were only found along the banks. This was due to the strong current $(0.61$ $\mathrm{m} / \mathrm{sec}$ ) of the river.

Of 80 sites in the Perupuk area (Fig. 1-B), water hyacinth was found at 32 sites before the influx of the equinoctial spring tide (EST) at the end of April 1986. Water hyacinths growing at 19 of 32 sites were then affected by the inflow of sea water coming through each tidal creek. Afterwards, water hyacinths recovered their former state at 15 sites, but died out at the other 4 sites. Instead, duck weed started to grow at these 4 sites. Duck weed distributed at 6 sites before the EST influx, afterwards the 4 sites were therefore added. No vegetation was recorded at 42 sites before the EST influx, and afterwards the 19 sites which were affected by the EST influx were temporarily added.

The relationship between $A n$. sundaicus larval density and water salinity in areas 

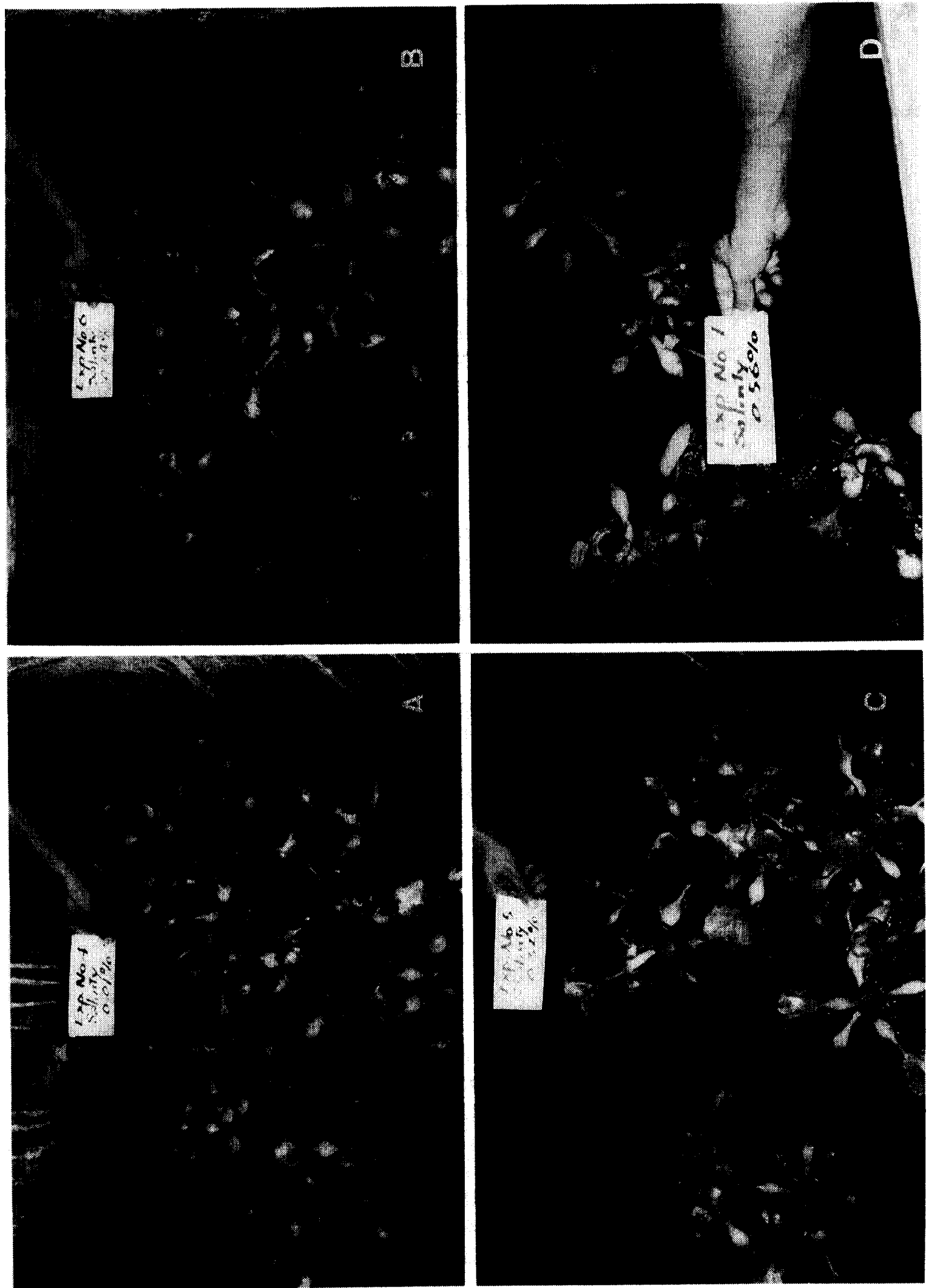

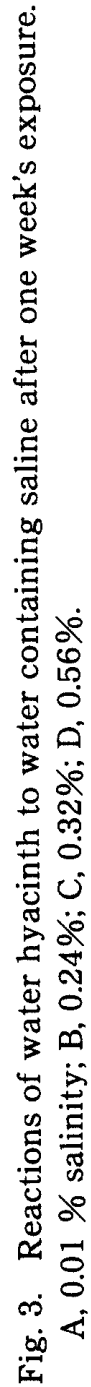


with water hyacinth, duck weed (Spirodela spp.), and/or no vegetation growth are shown in Fig. 2. Of a total of 553 samples, 174 samples were collected from the sites where there were water hyacinth growing. The salinity of the water where hyacinth grew was less than $0.2 \%$. No $A n$. sundaicus larva was found breeding in the waters with hyacinth. Fifty-seven samples were collected from the duck weed breeding waters, where salinity was measured at between $0.0 \%$ and $1.2 \%$. An. sundaicus larvae were found in 12 samples. The other 322 samples were collected from waters with no vegetation. The range of salinity in those samples was $0.0 \%$ to $4.0 \%$. The larval positive rate of 322 samples was $49 \%$ and the larval density per dip was $0.819 \pm 0.175$ (S.E.). In 42 samples from waters with no vegetation, though the salinity was less than $0.2 \%$, larvae were found in 13 samples and the mean larval density per dip was recorded at $0.161 \pm 0.178$ (S.E.). Larvae, therefore, existed in water of $<0.2 \%$ salinity.

In the fresh water ponds (thick arrow in Fig. 1-B) which are situated behind sand banks running parallel to the shore, a dense growth of water hyacinth was found. This survey site was surrounded by several $A n$. sundaicus breeding sites. Although this site was located only $40 \mathrm{~m}$ from the seashore, larvae were not collected there from September 1985 to August 1986.

\section{The susceptibility of water hyacinth to salin-} ity

In the first two days after exposure to water containing saline, the hyacinths were more thriving at $0.24 \%$ salinity than those at $0.01 \%$. A striking difference was found in the reactions of the leaf stalk forms after 2 days' exposure to $0.24 \%$ and $0.32 \%$ salinity. The water hyacinth could not tolerate $0.32 \%$ salinity and began withering. The reaction of water hyacinth to different salinities after one week is shown in Fig. 3. Almost all the leaf stalks in water with $0.32 \%$ salinity had withered further and their roots had become wavy and shortened. Water hyacinth exposed to $0.56 \%$ salinity were more severely affected than those at $0.32 \%$ or $0.24 \%$.

\section{Discussion}

On the coastal plain area of Asahan Province there are river mouths, coastal bays, tidal marshes, and water bodies between sand banks. In this environment, the boundaries of $A n$. sundaicus habitat fluctuate greatly. One consistent indicator of the presence of $A n$. sundaicus is the nonexistence of water hyacinth.

For An. sundaicus larval breeding, floating Pteridophyta, Salvinia sp., was mentioned by Imai et al. (1988). They reported that larvae were never collected in waters with this plant in Perupuk, and this plant grew in waters with $0.03-0.30 \%$ salinity and covered the entire surface of those with less than $0.1 \%$ salinity. It was speculated that floating plants including water hyacinth and duck weed may have the effect of shading the water surface for $A n$. sundaicus oviposition. In malaria vector control to target "preferred" breeding sites and to distinguish "non-breeding" sites can provide a cost-effective and rational approach. The usefulness of Salvinia sp. in the control was limited because the distribution of this plant was very limited in the study area.

Observation of the distribution of water hyacinth vegetation in this area led us to believe that its presence might indicate an existing border between brackish water and fresh water. The salinity of $A n$. sundaicus habitats was reported to be $0.4^{-}$ 3.0\% (optimum: $1.5-2.0 \%$ ) in Mid Java (Sundararaman et al., 1957) and 0.5-1.0\% in South Sulawesi (Collins et al., 1979). In North Sumatra, it was 0.0-1.8\% (Ikemoto, 1982). Imai and Panjaitan (1990) also mentioned that the optimum range was $0.5-0.8 \%$. In our survey, $A n$. sundaicus larvae were collected in waters where the range of salinity was $0.0-4.0 \%$. The different levels of salinity in larval habitat of 
An. sundaicus may be due to the instability of water conditions along coastal flats affected by tide movement. It must, therefore, be concluded that salinity is not the ultimate indicator of $A n$. sundaicus breeding but it is helpful. An. sundaicus larvae were found in water where the salinity was at or below $0.2 \%$, only when water hyacinth was absent. Other anopheline mosquitoes and Mansonia spp., however, were commonly collected in waters with this plant. These environmental factors do not determine the existence of $A n$. sundaicus larval breeding. The only noticeable difference was the existence of water hyacinth. Our observation on the distribution of water hyacinth vegetation will provide more precise information about the present condition of these malaria vector habitats.

\section{ACKNOWLEDGMENTS}

We are grateful to the staff members of the Malaria Division, Department Kesehatan, Provinsi Sumatra Utara, who kindly assisted the study, especially to $\mathrm{Mr}$. Halomoan Sirait, Mr. Wesly Pohan and Mr. Halomoan Hasibuan, for their valuable assistance. This study was carried out as a part of the North Sumatra Health Promotion Project which was supported by the Ministry of Health, Indonesia, and the Japan International Cooperation Agency.

\section{REFERENCES}

Chan, K. L. (1969) A study on Anopheles maculatus and Anopheles sundaicus in Singapore. Singapore Med. J., 10: 57-63.

Collins, R. T., R. K. Jung, H. Anoez, R. H. Sutrisno and D. Putut (1979) A study of the coastal malaria vectors, Anopheles sundaicus (Rodenwaldt) and Anopheles subpictus Grassi, in South Sulawesi, Sulawesi, Indonesia. $W H O / V B C / 79,740: 1-12$.

Gabinaud, A. (1987) Ecological mapping to support mosquito control on the French Mediterranean Coast. Parasitol. Today, 3: 317-320.

Ikemoto, T. (1982) Studies on the bionomics of Anopheles sundaicus (Rodenwaldt, 1925), the principal malaria vector in a coastal area of North Sumatra, Indonesia. Teikyo Med. J., 5: 1-15 (in Japanese with English summary).

Imai, C., T. Ikemoto, M. Takagi, H. Yamugi, W. Pohan, H. Hasibuan, H. Sirait and W. Panjaitan (1988) Ecological study of Anopheles sundaicus larvae in coastal village of North Sumatra, Indonesia. I. Topography, land use and larval breeding. Jpn. J. Sanit. Zool., 39: 293-300.

Imai, C. and W. Panjaitan (1990) Ecological study of Anopheles sundaicus larvae in coastal village of North Sumatra, Indonesia. II. Environmental factors affecting larval density of $A n$. sundaicus and other anopheline species. Jpn. J. Sanit. Zool., 41: 205-211.

Kanbara, H. and W. Panjaitan (1983) The epidemiological survey of malaria in Asahan district, North Sumatra, Indonesia. Jpn. J. Trop. Med. Hyg., 11: 1724.

Sundararaman, S., R. M. Soeroto and M. Siran (1957) Vectors of malaria in Mid-Java. J. Malariol., 11: 321-338.

\section{摘要}

An. sundaicus 幼虫生息場所の環境指標としての ホテイアオイの有用性について

菊池哲志(1)31 高木正洋(1) 4) 徳久英二11,5) 鈴木 猛1,6) Panjaitan W.2) 安野正之 ${ }^{1,7)}$

1) 北スマトラ地域保健対策プロジェクト

インドネシア共和国北スマトラ州保健局

2) インドネシア共和国北スマトラ州保健局

3) 帝京大学医学部医動物学教室

（票173 東京都板橋区加賀 2-11-1）

4) 長崎大学熱帯医学研究所生物環境分野 （干852 長崎市坂本 1-12-4）

5) 株式会社帝装化成学術研究部 （兵321-01 宇都宮市大和 1-9-19）

6)（テ158 東京都世田谷区玉堤 1-4-5）

7) 滋賀県立大学環境科学部環境生態学科 （开522 彦根市八坂 2500）

北スマトラ州のアサハン地区の海岸部において, $A n$. sundaicus 幼虫の生息場所の分布を敏速に把握するため に，ホテイアオイの植生が指標として役立つかどうか調 査した。 ホテイアオイは塩分濃度 $0.2 \%$ 以下の水域に広 く繁茂し，これらの水域加 An. sundaicus は採集され なかった。一方，ホテイアオイ非植生水域（塩分濃度 0.0 〜4.0\%）からは本幼虫が頻繁に採集された. ホテイアオ イ植生水域に海水が侵入した場合を想定して，ホテイア オイの塩分耐性を調べたところ，0.32\% 以上の塩分濃度 に対してすぐに萎れ始めた。これらの結果から，ホテイ アオイの植生分布とその外部形態の変化は, An. sunda$i c u s$ 幼虫生息場所の指標として有用であると考えた. 